\title{
Characteristics of soil nutrients and their relationship with soil microbial properties in Artemisia sacrorum communities in the loess hilly region
}

\author{
Lijuan Song ${ }^{1,2}$, Weiyang $\mathrm{Liu}^{3}$, Huifeng $\mathrm{Wu}^{1}$, Tian $\mathrm{GaO}^{4}$, Wenfang $\mathrm{Hao}^{{ }^{*}}$ \\ (1. College of Life Sciences, Northwest A\&F University, Yangling 712100, China; \\ 2. College of Life Sciences, Cangzhou Normal University, Cangzhou 061000, China; \\ 3. College of Plant and Science, Tarim University, Alar, Xinjiang 843300, China; \\ 4. College of Landscape Architecture and Arts, Northwest A\&F University, Yangling 712100, China)
}

\begin{abstract}
Artemisia sacrorum communities with different growth years were selected to analyse soil nutrient characteristics, the variation in soil microbial properties, and their relationships in the loess hilly region. The results showed that with an increase in the number of growth years, soil microbial biomass carbon and nitrogen contents as well as soil phosphatase and urease activities initially decreased and then increased in the A. sacrorum communities. The soil organic carbon, organic nitrogen, and total nitrogen contents as well as soil respiration rate showed an increasing trend and reached a maximum at age (a) 37. The soil available phosphorus content first decreased and then increased, with the lowest level observed at 18 a. By contrast, soil available potassium initially increased and then decreased. Soil microbial biomass carbon had a significant positive correlation with soil organic carbon, total nitrogen and organic nitrogen, while soil respiration had a significant positive correlation with organic nitrogen, soil phosphatase and organic carbon. Soil respiration had a highly significant positive correlation with organic carbon and total nitrogen, while soil phosphatase had a highly significant positive correlation with total nitrogen and organic nitrogen. In the A. sacrorum communities, the soil organic carbon and total nitrogen contents were mainly affected by soil respiration, soil available potassium content was mainly affected by soil urease activity, and soil organic nitrogen content was mainly affected by soil phosphatase activity. These findings indicate that soil basal respiration, urease activity and phosphatase activity were the major microbial factors affecting the characteristics of the soil nutrients in the $A$. sacrorum communities. In conclusion, the natural restoration process of $A$. sacrorum communities can enhance soil microbial activity and improve soil quality.
\end{abstract}

Keywords: loess hilly, soil nutrients, soil microbial biomass, soil enzyme activities, soil basal respiration rate DOI: $10.25165 /$ j.ijabe.20181104.3942

Citation: Song L J, Liu W Y, Wu H F, Gao T, Hao W F. Characteristics of soil nutrients and their relationship with soil microbial properties in Artemisia sacrorum communities in the loess hilly region. Int J Agric \& Biol Eng, 2018; 11(4): 127-134.

\section{Introduction}

Soil is the basis of vegetation survival. It provides water and various nutrients for the growth and reproduction of vegetation, affecting the rate and process of vegetation restoration. Being an important component of the soil ecosystem, microbes participate in the transformation and cycling of soil nutrients, influence vegetation nutrition and soil fertility, and have become an important indicator for evaluating soil quality ${ }^{[1]}$. Soil microbial properties are important indicators used in the evaluation of soil fertility and are sensitivity parameters for soil health status. The soil microbial biomass is a storage pool of soil active nutrients, and it can directly reflect the actual content of microbes and the

\section{Received date: 2017-11-06 Accepted date: 2018-03-16}

Biographies: Lijuan Song, MS candidate, research interests: vegetation ecology, Email: songlijuan2017@163.com; Weiyang Liu, PhD candidate, Associate Professor, research interests: soil carbon-nitrogen cycle of desert-oasis ecotone, Email: 1wyzky@163.com; Wu Huifeng, MS candidate, research interests: vegetation ecology, Email: wuhuifeng2015@163.com; Tian Gao, Professor, research interests: landscape ecology. Northwest Agriculture and Forestry University of Science and Technology, Yangling 712100, China. Email: tian.gao@nwsuaf.edu.cn.

*Corresponding author: Wenfang Hao, Professor, research interests: vegetation ecology. Northwest A\&F University, Yangling 712100, China. Tel: +86-13572931268, Email: haowenfang@nwsuaf.edu.cn. transformation of nutrients in the soil ${ }^{[2]}$. Soil microbes are highly sensitive to variations in soil conditions and can provide an early indication of the variation in ecosystem structure and function. Thus, the amount of soil microbial biomass and its variation are commonly regarded as important indicators for soil quality ${ }^{[3]}$. The study of soil microbial biomass is of great significance to understand soil fertility, the availability of soil nutrients, and their transformation and cycling processes ${ }^{[4]}$. The intensity of soil basal respiration (SBR), an important activity indicator of soil microbes, can also be used to evaluate soil fertility ${ }^{[5]}$. The SBR intensity represents the amount and activity of microbial biomass, indicating the trends in soil quality and the maturity of soil ecosystems. Soil enzyme activity characterizes the direction and intensity of biochemical reactions ${ }^{[6]}$. In the process of vegetation restoration, soil microbial biomass and soil nutrient status had more consistent improvement; soil microbe metabolic activity significantly effects soil chemistry; and soil microbes became more sensitive to the evolution of soil fertility. As biological indicators for evaluating soil quality, soil microbial biomass carbon (MBC), nitrogen (MBN) and phosphorus show feasibility and cooperativity $^{[7]}$. In recent years, relevant studies have been conducted mainly with respect to grazing intensity, vegetation type, and altitude ${ }^{[8-10]}$. Little research investigated the variation in the relationship between community microbial properties and soil nutrients with growth years. 
Artemisia sacrorum is a relatively stable zonal vegetation in the hilly-gully region of the Loess Plateau and has become the most important community in the study of vegetation restoration ${ }^{[1]}$. Existing studies of A. sacrorum communities have mainly focused on the variation in soil nutrients, vegetation characteristics and their relationships ${ }^{[12]}$. In the present study, we selected $A$. sacrorum communities in the loess hilly region of northern Shaanxi in China to analyse the variation in soil nutrient characteristics and their relationships with soil microbial properties. The objectives of the study were to clarify the variation in the soil microbial properties of the $A$. sacrorum communities with growth years and to explore the major microbial factors that affect the soil nutrient characteristics in the A. sacrorum communities. This study provides basic data for understanding the soil system in the study area and presents scientific evidence for better construction of $A$. sacrorum communities during land improvement, soil ecological restoration and vegetation restoration in this region.

\section{Materials and methods}

\subsection{Description of the study site}

The study site is located in Ansai County (108 $5^{\prime} 44^{\prime \prime}$ $\left.109^{\circ} 26^{\prime} 18^{\prime \prime} \mathrm{E}, 36^{\circ} 30^{\prime} 45^{\prime \prime}-37^{\circ} 19^{\prime} 31^{\prime \prime} \mathrm{N}\right)$, China. This region has a temperate semi-arid continental monsoon climate. The average annual precipitation is $513 \mathrm{~mm}$, annual evaporation is $1490 \mathrm{~mm}$, and the average frost-free period lasts $157 \mathrm{~d}$. The vegetation zone belongs to forest steppe that changes from warm temperate deciduous broad-leaved forest to arid steppe. The major species of grassland are Artemisia scoparia, Artemisia sacrorum, Lespedeza davurica, Bothriochloa ischaemum and Stipa bungeana.

\subsection{Experimental design and soil sampling}

Through the visits to local residents and field surveys, combined with different geographical factors and other factors, we selected natural $A$. sacrorum communities with no human disturbance and growth years of 5 a, 10 a, 15 a, 18 a, 29 a and 37 a as experimental sites (Figure 1). These sites had similar slop gradients, slope aspects and elevation. Three $20 \mathrm{~m} \times 20 \mathrm{~m}$ plots were established at each site. The plot environmental status was measured and recorded using a global positioning system (GPS; Table 1). During July $10-20$, 2016, five $1 \mathrm{~m} \times 1 \mathrm{~m}$ quadrats were set up in each plot. Soil samples were collected using a soil auger at depths of $0-5 \mathrm{~cm}, 5-10 \mathrm{~cm}, 10-20 \mathrm{~cm}$ and $20-40 \mathrm{~cm}$. Five replicates were set up in an S-shaped pattern in each plot. The five replicate soil samples from the same plot were mixed for a particular soil layer to form one sample. The samples were transported to the laboratory and divided into two portions. One part of the fresh sample was filtrated by a $2 \mathrm{~mm}$ sieve after removal of plant residues and soil animals in order to measure MBC, MBN and SBR intensity, and the other part was air-dried, reduced to the required soil volume by quartering for the analysis of soil nutrients and enzymes.


Figure 1 Location of the Loess Plateau and the study site

Table 1 General information of the sample plots

\begin{tabular}{|c|c|c|c|c|}
\hline Age/a & Aspect & Slope gradient $/\left({ }^{\circ}\right)$ & Altitude $/ \mathrm{m}$ & $\begin{array}{c}\text { Latitude and } \\
\text { longitude }\end{array}$ \\
\hline 5 & Shady slope & 45 & 1258 & $\begin{array}{l}\text { N36 } 39.396^{\prime} \\
\text { E109 } \\
\end{array}$ \\
\hline 10 & Shady slope & 34 & 1269 & $\begin{array}{c}\mathrm{N}^{3} 36^{\circ} 39.416^{\prime} \\
\mathrm{E} 109^{\circ} 11.899^{\prime}\end{array}$ \\
\hline 15 & Shady slope & 29 & 1230 & $\begin{array}{l}\mathrm{N} 36^{\circ} 39.367^{\prime} \\
\mathrm{E} 109^{\circ} 11.800^{\prime}\end{array}$ \\
\hline 18 & Shady slope & 32 & 1256 & $\begin{array}{l}\mathrm{N} 36^{\circ} 39.691^{\prime} \\
\mathrm{E} 109^{\circ} 11.862^{\prime}\end{array}$ \\
\hline 29 & Shady slope & 29 & 1247 & $\begin{array}{l}\mathrm{N} 36^{\circ} 39.604^{\prime} \\
\mathrm{E} 109^{\circ} 11.847^{\prime}\end{array}$ \\
\hline 37 & Shady slope & 42 & 1257 & $\begin{array}{l}\mathrm{N} 36^{\circ} 39.565^{\prime} \\
\text { E109 } \\
\end{array}$ \\
\hline
\end{tabular}

Note: For the aspect and slope gradient, due north is defined as $0^{\circ}$, and a clockwise circle is defined as $360^{\circ}$.

\subsection{Sample analysis}

Soil total nitrogen (TN) was determined using the semi-micro Kjeldahl method $\left(\mathrm{K}_{2} \mathrm{SO}_{4}-\mathrm{CuSO}_{4}\right.$-Se distillation method). Available nitrogen (AN) was analysed using the alkaline hydrolysis diffusion method. Available phosphorus (AP) was determined using the $0.5 \mu \mathrm{g} / \mathrm{L} \mathrm{NaHCO}_{3}$ method. Available potassium (AK) was extracted with $\mathrm{NH}_{4} \mathrm{OAc}$ and determined using flame photometry. Organic carbon (OC) was determined using the potassium dichromate volumetric-external heating method ${ }^{[13]}$. MBC and MBN were analysed using the chloroform-fumigation extraction method ${ }^{[14]}$. SBR was determined using the alkali absorption method ${ }^{[15]}$. Soil urease was analysed using the phenol-sodium hypochlorite colorimetric method, and soil alkaline phosphatase was analysed using the disodium phenyl phosphate colorimetric method ${ }^{[16]}$.

\subsection{Data analysis}

Data were statistically analysed using Excel 2007 and SPSS 
18.0. Plots were drawn using Origin 9.0. Significant differences in the soil nutrient characteristics and microbial properties of the $A$. sacrorum communities with different growth years were evaluated using one-way ANOVA and Duncan's multiple comparisons test. The correlation between various indicators was tested using Pearson's correlation coefficient. The major microbial factors that influenced the soil nutrient characteristics of the A. sacrorum communities were determined using stepwise regression analysis.

\section{Results}

3.1 Variation in the soil microbial properties of $A$. sacrorum communities

3.1.1 Variation in the soil microbial biomass and SBR of $A$. sacrorum communities

Soil microbial biomass and SBR was affected by the continuous growth of $A$. sacrorum. Table 2 showed that with increasing growth years of $A$. sacrorum communities, both MBC and MBN initially decreased and recovered later, whereas SBR generally showed an increasing trend in the $0-5 \mathrm{~cm}$ and $5-10 \mathrm{~cm}$ soil layers. Soil MBC in the A. sacrorum communities with different growth years showed the following descending trend: 29 a,
37 a, 18 a, 15 a, 5 a, 10 a in $0-5 \mathrm{~cm}$ soil layer and 37 a, 18 a, 29 a, $15 \mathrm{a}, 5 \mathrm{a}, 10 \mathrm{a}$ in the $5-10 \mathrm{~cm}$ soil layer. Soil MBN exhibited the following descending trend: 37 a, 29 a, 18 a, 15 a, 5 a, 10 a in the 0-5 cm soil layer and 29 a, 37 a, 5 a, 18 a, 15 a, 10 a in the $5-10 \mathrm{~cm}$ soil layer. SBR decreased as follows: 37 a, 29 a, 10 a, 18 a, 5 a, $15 \mathrm{a}$ in the 5-10 cm soil layer and $37 \mathrm{a}, 29 \mathrm{a}, 18 \mathrm{a}, 15 \mathrm{a}, 5 \mathrm{a}, 10 \mathrm{a}$ in the $5-10 \mathrm{~cm}$ soil layer. MBC, MBN, and SBR were higher in the surface layer than in the bottom layer.

In the $0-5 \mathrm{~cm}$ soil layer, $\mathrm{MBC}$ did not differ significantly between the $18 \mathrm{a}$ and $37 \mathrm{a}$ communities, whereas significant differences were found between the other growth years. In the $5-10 \mathrm{~cm}$ soil layers, there were significant differences between the A. sacrorum communities of each growth years. MBN showed significant differences in both the $0-5 \mathrm{~cm}$ and $5-10 \mathrm{~cm}$ soil layers between the $A$. sacrorum communities. The 29 a $A$. sacrorum community exhibited significantly higher SBR in the $0-5 \mathrm{~cm}$ soil layer than the 5 a, 10 a, 15 a and 18 a communities but exhibited significantly lower SBR compared with the 37 a community. The 5 a and 10 a $A$. sacrorum communities showed no significant difference in SBR in the $5-10 \mathrm{~cm}$ soil layers, but they differed significantly compared with the other growth years.

Table 2 Soil microbial biomass and soil respiration in Artemisia sacrorum communities with different growth years

\begin{tabular}{|c|c|c|c|c|c|c|}
\hline \multirow{2}{*}{ Age/a } & \multicolumn{2}{|c|}{ Microbial biomass carbon $/ \mathrm{mg} \cdot \mathrm{kg}^{-1}$} & \multicolumn{2}{|c|}{ Microbial biomass nitrogen $/ \mathrm{mg} \cdot \mathrm{kg}^{-1}$} & \multicolumn{2}{|c|}{ Soil basal respiration $/ \mathrm{mg} \cdot(\mathrm{kg} \cdot \mathrm{d})^{-1}$} \\
\hline & $0-5 \mathrm{~cm}$ & $5-10 \mathrm{~cm}$ & $0-5 \mathrm{~cm}$ & $5-10 \mathrm{~cm}$ & $0-5 \mathrm{~cm}$ & $5-10 \mathrm{~cm}$ \\
\hline 5 & $189.02 \pm 1.02 \mathrm{~d}$ & $50.79 \pm 0.81 \mathrm{e}$ & $13.96 \pm 0.07 \mathrm{e}$ & $12.05 \pm 0.05 \mathrm{c}$ & $134.29 \pm 2.02 \mathrm{~d}$ & $102.58 \pm 1.69 \mathrm{e}$ \\
\hline 10 & $127.11 \pm 0.45 \mathrm{e}$ & $48.25 \pm 0.71 \mathrm{f}$ & $9.52 \pm 0.18 \mathrm{f}$ & $5.43 \pm 0.02 \mathrm{f}$ & $139.91 \pm 1.85 \mathrm{c}$ & $99.25 \pm 2.62 \mathrm{e}$ \\
\hline 15 & $202.26 \pm 0.45 \mathrm{c}$ & $65.15 \pm 0.24 d$ & $16.72 \pm 0.08 \mathrm{~d}$ & $9.31 \pm 0.01 \mathrm{e}$ & $134.02 \pm 3.19 \mathrm{~d}$ & $112.21 \pm 1.37 \mathrm{~d}$ \\
\hline 18 & $235.36 \pm 1.42 b$ & $88.39 \pm 0.39 b$ & $20.95 \pm 1.03 \mathrm{c}$ & $10.13 \pm 0.01 \mathrm{~d}$ & $137.21 \pm 2.12 \mathrm{~cd}$ & $129.89 \pm 2.10 \mathrm{c}$ \\
\hline 37 & $235.95 \pm 4.07 \mathrm{~b}$ & $113.77 \pm 0.68 \mathrm{a}$ & $30.31 \pm 0.75 \mathrm{a}$ & $17.77 \pm 0.03 b$ & $250.09 \pm 1.73 a$ & $184.46 \pm 2.00 \mathrm{a}$ \\
\hline
\end{tabular}

Note: Different lowercase letters within a column indicate significant differences in $A$. sacrorum communities with different growth years $(p<0.05)$. The same applies to the following tables.

3.1.2 Variation in the soil enzyme activities of the A. sacrorum communities

Soil phosphatase and urease activity initially decreased and then recovered with increasing growth years of the A. sacrorum communities in all of the $0-10 \mathrm{~cm}, 10-20 \mathrm{~cm}$, and $20-30 \mathrm{~cm}$ soil layers; the highest value appeared at 37 a (Table 3 ). The lowest phosphatase activity appeared at $15 \mathrm{a}$ in both the $0-10 \mathrm{~cm}$ and 20 $40 \mathrm{~cm}$ soil layers, compared with $10 \mathrm{a}$ in the $10-20 \mathrm{~cm}$ soil layer. Soil urease activity ranked the lowest at 15 a in both the $0-10 \mathrm{~cm}$ and $10-20 \mathrm{~cm}$ soil layers, while the lowest value was observed at $10 \mathrm{a}$ in the $20-40 \mathrm{~cm}$ soil layer.
In the vertical direction, both soil phosphatase and urease activities decreased gradually with increasing soil depth. In the 0-10 cm soil layer, soil phosphatase activity did not significantly differ between the 5 a, 10 a and 15 a communities, while the difference between other communities was significant. The 37 a A.sacrorum community showed significantly different soil phosphatase activity in the $10-20 \mathrm{~cm}$ soil layer and soil urease activity in the $20-40 \mathrm{~cm}$ soil layer compared with the other growth years. Soil phosphatase activity in the $20-40 \mathrm{~cm}$ soil layer and soil urease activity in the $10-20 \mathrm{~cm}$ soil layer differed significantly among the $A$. sacrorum communities.

Table 3 Soil enzyme activities in Artemisia sacrorum communities with different growth years

\begin{tabular}{|c|c|c|c|c|c|c|}
\hline \multirow{2}{*}{ Age/a } & \multicolumn{3}{|c|}{ Phosphatase activity $\left(\mathrm{mg} \cdot \mathrm{g}^{-1}, 37^{\circ} \mathrm{C}, 24 \mathrm{~h}\right)$} & \multicolumn{3}{|c|}{ Urease activity $\left(\mathrm{mg} \cdot \mathrm{g}^{-1}, 37^{\circ} \mathrm{C}, 24 \mathrm{~h}\right)$} \\
\hline & $0-10 \mathrm{~cm}$ & $10-20 \mathrm{~cm}$ & $20-40 \mathrm{~cm}$ & $0-10 \mathrm{~cm}$ & $10-20 \mathrm{~cm}$ & $20-40 \mathrm{~cm}$ \\
\hline 5 & $0.062 \pm 0.003 \mathrm{~d}$ & $0.019 \pm 0.001 \mathrm{c}$ & $0.009 \pm 0.001 \mathrm{c}$ & $0.098 \pm 0.007 \mathrm{a}$ & $0.042 \pm 0.003 \mathrm{~b}$ & $0.019 \pm 0.0008 \mathrm{~b}$ \\
\hline 10 & $0.06 \pm 0.002 \mathrm{~d}$ & $0.018 \pm 0.001 \mathrm{c}$ & $0.0088 \pm 0.002 \mathrm{~d}$ & $0.08 \pm 0.003 b$ & $0.02 \pm 0.002 \mathrm{e}$ & $0.006 \pm 0.0006 \mathrm{~d}$ \\
\hline 15 & $0.057 \pm 0.003 \mathrm{~d}$ & $0.022 \pm 0.002 b$ & $0.0031 \pm 0.001 \mathrm{f}$ & $0.067 \pm 0.006 \mathrm{c}$ & $0.016 \pm 0.001 \mathrm{f}$ & $0.007 \pm 0.0008 \mathrm{~d}$ \\
\hline 18 & $0.069 \pm 0.003 \mathrm{c}$ & $0.024 \pm 0.002 b$ & $0.0038 \pm 0.002 \mathrm{e}$ & $0.075 \pm 0.004 b c$ & $0.027 \pm 0.0004 \mathrm{~d}$ & $0.013 \pm 0.0006 \mathrm{c}$ \\
\hline 37 & $0.1 \pm 0.008 \mathrm{a}$ & $0.031 \pm 0.001 \mathrm{a}$ & $0.0125 \pm 0.005 \mathrm{a}$ & $0.103 \pm 0.004 \mathrm{a}$ & $0.048 \pm 0.001 \mathrm{a}$ & $0.023 \pm 0.002 \mathrm{a}$ \\
\hline
\end{tabular}

3.1.3 Dynamic analysis of the variation in the soil microbial properties of $A$. sacrorum communities

As growth year increased, the soil microbial properties varied in the A. sacrorum communities (Figure 2). Soil MBC, MBN, and SBR showed an increasing trend as growth year increased.
However, the soil phosphatase and urease activities initially decreased and then recovered with growth year, and a maximum was reached at 37 a. The fitted equations are shown in Figure 2. The equation curves of soil MBC, MBN, and SBR, as well as phosphatase and urease activities, were well fitted. 

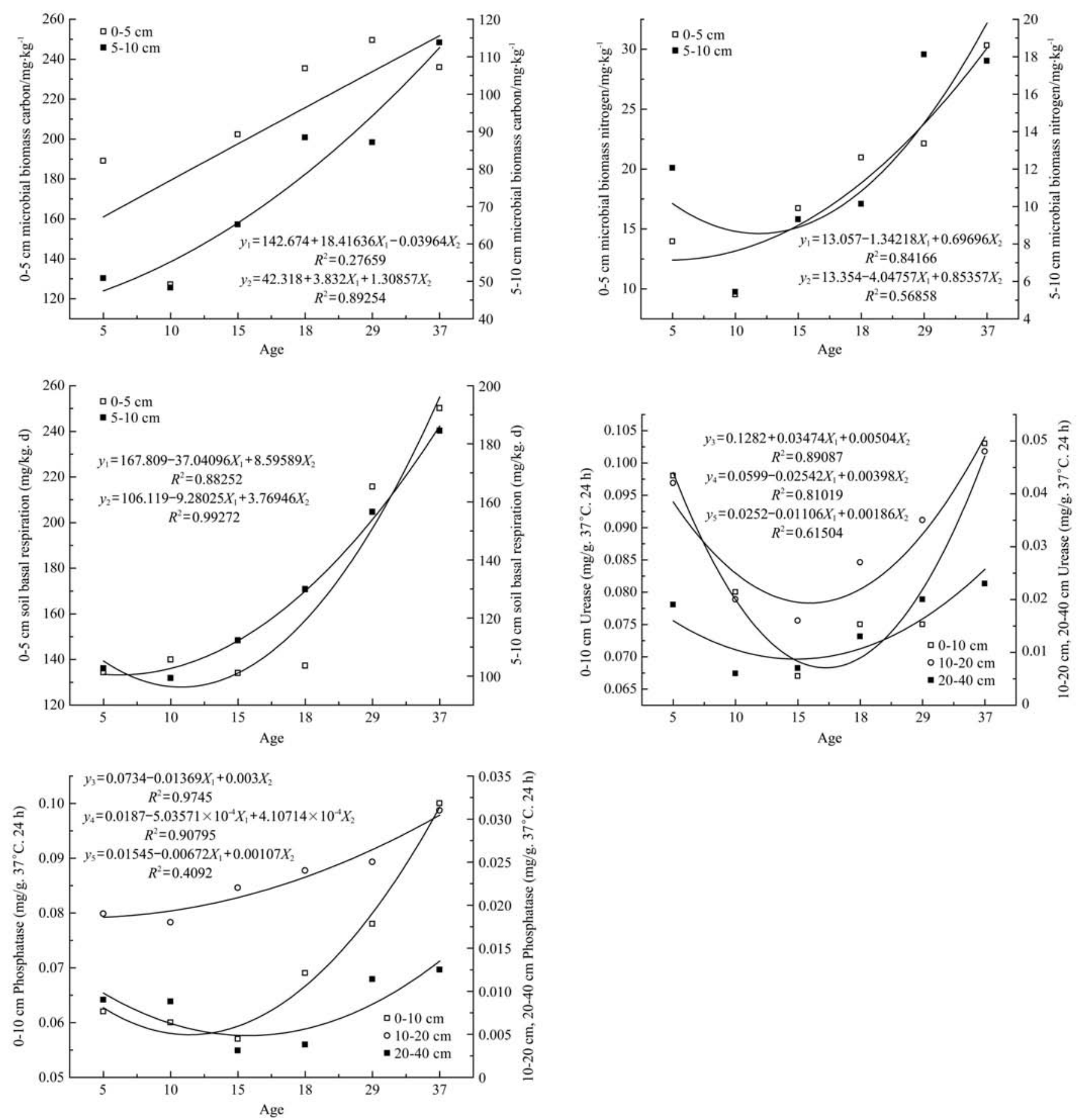

Note: $y_{1}$ : fitted equation for $0-5 \mathrm{~cm}$ soil layer; $y_{2}$ : fitted equation for 5-10 cm soil layer; $y_{3}$ : fitted equation for $0-10 \mathrm{~cm}$ soil layer; $y_{4}$ : fitted equation for $10-20 \mathrm{~cm}$ soil layer; $y_{5}$ : fitted equation for $20-40 \mathrm{~cm}$ soil layer.

Figure 2 Variationin the soil microbial properties of the A. sacrorum communities with different growth years

\subsection{Relationship between the soil microbial properties and} soil nutrients in $A$. sacrorum communities

3.2.1 Variationin the soil nutrient characteristics of $A$. sacrorum communities

As the growth year of the A. sacrorum communities increased, the belowground soil nutrient contents changed correspondently. As Figure 3 shows, OC, ON, and TN increased along with the growth year. Soil AP initially decreased before increasing in the 0-5 $\mathrm{cm}$ and 5-10 cm layers, whereas no significant change occurred in the 1-20 cm layer. The opposite trend was found in the soil AK content, which showed an increasing trend and followed by a decline. Among the A. sacrorum communities with different growth years, the variation in the soil $\mathrm{OC}, \mathrm{ON}$, and $\mathrm{TN}$ contents in the $0-5 \mathrm{~cm}, 5-10 \mathrm{~cm}$ and $10-20 \mathrm{~cm}$ soil layers was ranked as the following descending order: 37 a, 29 a, 18 a, 15 a, 10 a, 5 a. The variation in soil AP followed the descending order: $(5 \mathrm{a}=37 \mathrm{a})$, $10 \mathrm{a}, 15 \mathrm{a}, 29 \mathrm{a}, 18 \mathrm{a}$ in the $0-5 \mathrm{~cm}$ and $5-10 \mathrm{~cm}$ soil layers and $10 \mathrm{a}$, $(5 \mathrm{a}=37 \mathrm{a}), 18 \mathrm{a}, 15 \mathrm{a}, 29 \mathrm{a}$ in the $10-20 \mathrm{~cm}$ soil layer. The variation in soil $\mathrm{AK}$ was ranked as the following descending order: 15 a, 18 a, 29 a, 10 a, 5 a, 37 a in the $0-5 \mathrm{~cm}$ soil layer; 18 a, 15 a, 10 a, 5 a, 29 a, 37 a in the $5-10 \mathrm{~cm}$ soil layer; and 18 a, 15 a, 10 a, 29 a, 37 a, 5 a in the $10-20 \mathrm{~cm}$ soil layer. The variation in soil nutrients between different soil layers followed a decreasing trend with increasing soil depth. 

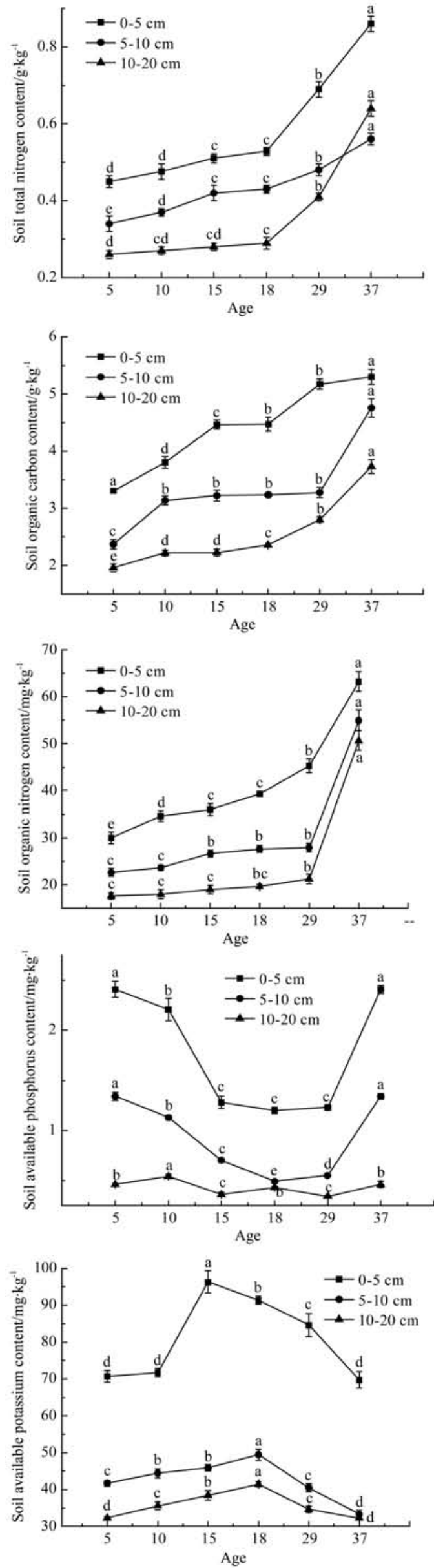

Figure 3 Characteristics of soil nutrients in A. sacrorum communities with different growth years
In the $0-5 \mathrm{~cm}$ layer, the soil OC content did not differ significantly between 18 a and 29 a, while significant differences were found among the other A. sacrorum communities. In the 5-10 cm layer, the 5 a and 37 a communities showed significant differences in the soil OC content compared with the other communities, while no significant differences were found among the other communities. In the $10-20 \mathrm{~cm}$ soil layer, there was no significant difference in the soil OC content between 10 a and $15 \mathrm{a}$, while these two communities differed significantly from the other communities. With regard to the $\mathrm{ON}$ content in the $0-5 \mathrm{~cm}$ soil layer, there was no significant difference between $15 \mathrm{a}$ and $18 \mathrm{a}$; however, significant differences were found when compared with the other communities. In the $5-10 \mathrm{~cm}$ soil layer, there was no significant difference in the ON content between 5 a and 10 a or between 15 a, 18 a and 29 a; the 37 a community differed significantly from the other communities. In the $10-20 \mathrm{~cm}$ soil layer, the ON content differed significantly between the $37 \mathrm{a}$ and other communities; the 29 a community did not differ significantly from the 18 a community but did differ significantly from the other communities. With respect to the soil TN content in the $0-5 \mathrm{~cm}$ soil layer, there was no significant difference between 5 a and 10 a, 15 a and 18 a, but a significant difference was found when compared with the other communities. In the $5-10 \mathrm{~cm}$ soil layer, the soil TN content did not differ significantly between 15 a and 18 a, but a significant difference was observed when compared with the other growth years. In the $10-20 \mathrm{~cm}$ soil layer, there were no significant differences between 5 a and 18 a or between $10 \mathrm{a}$ and $15 \mathrm{a}$; the difference was significant when compared with the other growth years. Soil AP in the $0-5 \mathrm{~cm}$ soil layer did not differ significantly between $5 \mathrm{a}$ and 37 a or among 15 a, 18 a, and 29 a, but a significant difference was found between 10 a and the other growth years. In the $5-10 \mathrm{~cm}$ soil layer, soil AP did not differ significantly between 5 a and 37 a, but a significant difference was detected when compared with the other growth years. In the 10-20 cm soil layer, a significant difference was observed in soil AP between the 10 a and other growth years. Soil AK in the $0-5 \mathrm{~cm}$ soil layer did not differ significantly among $5 \mathrm{a}, 10 \mathrm{a}$ and $37 \mathrm{a}$; however, a significant difference was detected when compared with the other growth years. In the $5-10 \mathrm{~cm}$ soil layer, soil AK did not differ significantly between 5 a and 29 a or between 10 a and 15 a; however, a significant difference was detected when compared with the other growth years. In the $10-20 \mathrm{~cm}$ soil layer, there was no significant difference between $5 \mathrm{a}$ and $37 \mathrm{a}$ or between $10 \mathrm{a}$ and $29 \mathrm{a}$; however, a significant difference was detected when comparing the other growth years.

3.2.2 Correlation analysis of the soil nutrient characteristics and microbial properties of $A$. sacrorum communities

The correlation analysis results are shown in Table 4. Soil OC was positively, but not significantly, correlated with MBC. OC had a significant positive correlation with MBN $(p<0.05)$ and a highly significant positive correlation with $\mathrm{TN}$ and $\mathrm{ON}(p<0.01)$. AK was significantly negatively correlated with AP. TN showed a significant positive correlation with $\mathrm{MBN}$ and a highly significant positive correlation with $\mathrm{ON}$. MBC was positively correlated with soil nutrient indicators except for AK. MBN was significantly positively correlated with $\mathrm{OC}, \mathrm{TN}$, and $\mathrm{ON}$ and highly significantly positively correlated with MBC. SBR was positively correlated with soil nutrient indicators (except for AK), as well as MBC and MBN. Specifically, SBR had a significant positive correlation with $\mathrm{ON}$ and a highly significant positive correlation 
with OC, TN, and MBN. Both phosphatase and urease activities were positively correlated with the soil indicators except for AK. In particular, phosphatase activity had a significant positive correlation with $\mathrm{OC}$ and $\mathrm{MBN}$ and a significant positive correlation with TN, ON, and SBR. These results indicate that as the growth year of the A. sacrorum communities increased, the soil microbial properties and nutrient conditions were improved and later reached consistent levels. The soil microbial properties had significant effects on the soil nutrients, and the soil microbes were sensitive to the evolution of soil fertility.

Table 4 Correlation coefficients between the soil nutrients and microbial properties of $A$. sacrorum communities with different growth years

\begin{tabular}{|c|c|c|c|c|c|c|c|c|c|c|}
\hline & $\mathrm{OC}$ & AK & $\mathrm{TN}$ & AP & $\mathrm{ON}$ & MBC & MBN & SBR & JXLSM & $\mathrm{NM}$ \\
\hline $\mathrm{OC}$ & 1 & & & & & & & & & \\
\hline $\mathrm{AK}$ & -0.247 & 1 & & & & & & & & \\
\hline $\mathrm{TN}$ & $0.967^{* *}$ & -0.441 & 1 & & & & & & & \\
\hline $\mathrm{AP}$ & -0.035 & $-0.872 *$ & 0.122 & 1 & & & & & & \\
\hline ON & $0.925^{* *}$ & -0.501 & $0.958^{* *}$ & 0.304 & 1 & & & & & \\
\hline $\mathrm{MBC}$ & 0.739 & 0.073 & 0.748 & -0.389 & 0.640 & 1 & & & & \\
\hline MBN & $0.836^{*}$ & -0.282 & $0.905^{*}$ & -0.072 & $0.818^{*}$ & $0.929 * *$ & 1 & & & \\
\hline SBR & $0.923 * *$ & -0.465 & $0.980 * *$ & 0.078 & $0.892 *$ & 0.768 & $0.924 * *$ & 1 & & \\
\hline JXLSM & $0.899 *$ & -0.559 & $0.972 * *$ & 0.234 & $0.938^{* *}$ & 0.723 & $0.899 *$ & $0.974 * *$ & 1 & \\
\hline $\mathrm{NM}$ & 0.366 & $-0.812^{*}$ & 0.578 & 0.635 & 0.622 & 0.395 & 0.633 & 0.609 & 0.717 & 1 \\
\hline
\end{tabular}

Note: OC: Organic carbon; AK: Available potassium; TN: Total nitrogen; AP: Available phosphorus; ON: Organic nitrogen; MBC: Microbial biomass carbon; MBN: Microbial biomass nitrogen; SBR: Soil basal respiration; JXLSM: Phosphatase; NM: Urease. $\quad * p<0.05 ; * * p<0.01$.

3.2.3 Effects of soil microbial factors on soil nutrient characteristics of $A$. sacrorum communities

Multiple stepwise regression analysis was conducted on the major indicators of the soil nutrients and soil microbial properties of the A. sacrorum communities with different growth ages. The optimal multiple regression equation was established and subjected to a significance test. Based on the $\mathrm{F}$ test, the $\mathrm{P}$ value in ANOVA was always lower than 0.05 , indicating that the regression was highly significant (Table 5). The major factor affecting the soil OC and TN contents in the A. sacrorum communities was SBR. The major factor affecting the soil AK content in the A. sacrorum communities was soil urease activity, and that affecting the soil ON content was soil phosphatase activity. Among the four equations, SBR was selected in two of them, soil urease was selected in one of them, and soil phosphatase was selected in one of them. These results indicate that SBR was a decisive indicator of the soil nutrient characteristics of the A. sacrorum communities. Soil urease and phosphatase were also two major factors that influenced the soil nutrient characteristics of the $A$. sacrorum communities.

Table 5 Stepwise multiple regression of soil nutrient characteristics and microbial factors in Artemisia sacrorum communities with different growth years

\begin{tabular}{lcccc}
\hline \multicolumn{1}{c}{ Stepwise multiple regression } & $R^{2}$ & $\begin{array}{c}\text { Standardized } \\
\text { regression coefficients }\end{array}$ & $F$ & $P$ \\
\hline $\mathrm{OC}=3.427+0.23 \mathrm{SBR}$ & 0.923 & SBR & 23.108 & 0.009 \\
$\mathrm{AK}=221.301-482.357 \mathrm{NM}$ & 0.812 & $\mathrm{NM}$ & 7.732 & 0.050 \\
$\mathrm{TN}=0.043+0.004 \mathrm{SBR}$ & 0.980 & $\mathrm{SBR}$ & 96.482 & 0.001 \\
$\mathrm{ON}=-54.650+1476.124$ JXLSM & 0.936 & JXLSM & 28.264 & 0.006 \\
\hline
\end{tabular}

Note: OC: Organic carbon; AK: Available potassium; TN: Total nitrogen; ON: Organic nitrogen; SBR: Soil basal respiration; JXLSM: Phosphatase; NM: Urease.

\section{Discussion}

Owing to their sensitivity to the environment, soil biological indicators are used as early warning biological indicators of soil changes. In particular, they have shown great superiority with respect to soil changes caused by soil management measures, different planting patterns and vegetation types ${ }^{[17]}$. Together with the emphasis on soil quality monitoring and evaluation, soil biological indicators have been used as sensitive, universal comprehensive indicators to evaluate soil quality. A high quality soil should possess good biological activity and stable microbial population composition ${ }^{[18]}$. Generally, microbial biomass and SBR are regarded as the conventional soil quality indicators that are most sensitive to soil quality changes ${ }^{[19]}$.

Soil nutrients are the main source of plant nutrition. The growth and development, as well as the nutrition and metabolism of plants, is closely related to the supply status of soil nutrients ${ }^{[20]}$. The initial stage of afforestation is characterized by individual species, sparse undergrowth vegetation, and a lack of biodiversity, with sparse litter and shallow roots. In addition, the microbial decomposition of the litter and roots is slow, and there is little replenishment of organic matter ${ }^{[21]}$. With the increase of the growth year of $A$. Sacrorum communities, plant species and species diversity increased in the community. The lush foliage and relatively developed photosynthetic organs ${ }^{[22]}$ enhance the enrichment of the soil nutrients. The thickness and annual accumulation of surface litter also gradually increase. After falling, decay and decomposition, all dry branches and leaf litter, as well as roots and deep debris, are released into the soil, promoting the storage and accumulation of soil $\mathrm{OC}^{[23]}$. The litter enters the soil and is decomposed by nitrogen-fixing bacteria and other microorganisms in the rhizosphere, thereby increasing the soil organic matter content. Vegetation mainly affects the soil OC content through the storage, composition and stability of OC by altering the quantity and quality of litter and its environmental conditions $^{[24]}$. The accumulation and depletion level of soil nitrogen depends on the accumulation and decomposition of soil $\mathrm{OC}^{[25]}$. Soil TN is closely related to the organic matter content; thus, variations in soil $\mathrm{ON}, \mathrm{TN}$, and $\mathrm{OC}$ show consistent trends. Due to the low soil OC content at the initial stage, the available substrates for soil microbes are limited, resulting in low soil microbial biomass ${ }^{[26]}$. However, with the development of a forest stand, the soil organic matter content increases; this adds to the available nutrients for soil microbes ${ }^{[27]}$ and significantly increases the soil microbial biomass. Thus, both MBC and MBN showed an initial decrease followed by an increase as the growth year of the 
A. sacrorum communities increased. The SBR rate depends on soil microbial biomass and substrate use efficiency ${ }^{[28]}$. Litter shows an increasing trend with an increase in growth year, which provides an increasing amount of substrates for microbes and results in an increasing trend in $\mathrm{SBR}^{[29]}$. Soil enzyme activities are closely associated with soil fertility, whereas soil MBC and MBN are the active parts of the soil organic matter pool and organic nitrogen pool, respectively ${ }^{[30]}$. Therefore, variations in soil enzyme activities and microbial biomass show similar trends. This suggests that the level of soil microbial biomass to some extent reflects the activity status of soil enzymes ${ }^{[31]}$. However, the variations in the soil $\mathrm{AK}$ and $\mathrm{AP}$ contents in the A. sacrorum communities showed inconsistent trends with $\mathrm{OC}, \mathrm{ON}$, and TN. This is because the variation in soil AK and AP contents is a highly complex issue. Potassium that is not directly available for uptake in the soil constitutes the majority of the soil total potassium content. Slowly released potassium constitutes the reserve of AK (mainly exchangeable potassium, also including water-soluble potassium). There is a slow reversible equilibrium between slowly released potassium and exchangeable potassium, in contrast to a rapid reversible equilibrium between exchangeable potassium and water-soluble potassium ${ }^{[32]}$. Phosphorus is mainly present in both organic and inorganic forms in the soil. Soil TP is an indicator that measures the sum of all forms of $\mathrm{P}$ in the soil, whereas AP indicates the phosphorus supply level in the soil. There exists a dynamic balance between these two forms. Soil AP is mainly affected by soil parent material, and it is less affected by phosphorus supply in the other forms ${ }^{[33]}$. The soil type in the study area is complex, mainly loess soil. In some areas, dark loessial(or Heilu) soil and grey cinnamon soil occur. The AP content is also affected by the climate, degree of weathering, leaching, TP content, and other factors ${ }^{[27]}$, which result in a complex variation in the soil AP content.

The soil surface layer has a high content of organic matter and nutrients (e.g., nitrogen), with good air water permeability, concentrated distribution of fine roots, and input of soil microbial metabolic substrates through litter ${ }^{[34]}$. These factors are conductive to soil microbial growth and reproduction, so that soil MBC and MBN contents, SBR, and soil enzyme activities decline with increasing soil depth. Moreover, the soil surface layer has superior natural factors and environmental conditions. Together with the loose structure and strong air permeability in the soil surface, soil microorganisms and soil hydrolases are mainly concentrated in this area, with intense activities. In the lower soil layer, the physical and chemical properties as well as the biological effects are relatively stable; the microbial decomposition is slow ${ }^{[11]}$. Thus, the soil nutrient content in the surface layer was higher than that in the lower soil layers of the A. sacrorum communities.

Soil microbial properties and soil nutrients are closely related and mutually affect each other. Microorganisms play a leading role in the decomposition and transformation of organic matter, which affect the energy flow and material transformation process in the ecosystem. The soil microbial biomass to a certain extent indicates the activity status of soil enzymes ${ }^{[35]}$. Urease and phosphatase are enzymes involved in nitrogen cycling, and both of them play a positive role in the synthesis of soil organic matter and humus ${ }^{[36]}$. Soil carbon, nitrogen, and phosphorus are the material basis for soil fertility and the main nutrient source needed for microbial growth; these elements can trigger soil enzyme activities and contribute to the decomposition of belowground dead roots and litter ${ }^{[37]}$. When the soil nutrient content increases, soil enzymes actively participate in their transformation and decomposition process and accelerate the accumulation of $\mathrm{MBC}$ and $\mathrm{MBN}^{[38]}$. It is well-known that soil biological (microbial and enzymatic) activities are involved in the metabolism of organic matter and are highly correlated with soil physicochemical properties, thus affecting the availability, accumulation and mineralization of soil nutrients ${ }^{[39]}$. In the case of good organic nutrient conditions, soil enzyme activities are relatively high; a higher intensity of mineralization of soil nutrient elements is more conducive to the cycling of nutrient materials within the system ${ }^{[40]}$. Previous studies have shown that the activities of ALP and URE had significant positive correlation with soil properties, particularly with soil $\mathrm{OC}$ and $\mathrm{TN}^{[41]}$. Both soil microbial biomass and soil enzyme activities are related to the above process to varying degrees. Thus, soil nutrient contents were significantly correlated with soil microbial properties in the A. sacrorum communities. The SBR rate depends on soil microbial biomass and substrate utilization efficiency ${ }^{[28]}$. Thus, SBR was significantly positively correlated with OC, while it had a highly significant positive correlation with $\mathrm{OC}, \mathrm{TN}$, and MBN. This suggests that SBR can indicate the trends of soil quality change and the maturity of the soil ecosystem in A. sacrorum communities.

\section{Conclusions}

As growth year increased, soil microbial biomass and enzyme activities initially decreased and then increased in the A. sacrorum communities; SBR increased gradually, indicating that the total activity of soil microorganisms tended to increase during the natural restoration of the A. sacrorum communities. Changes in the soil microbial properties would inevitably lead to corresponding changes in soil carbon and nitrogen cycles. Except for soil AP and $\mathrm{AK}$, the soil nutrient contents in the A. sacrorum communities increased as the growth year increased and reached a maximum at 37 a, with significantly improved soil quality. The cycling of soil nutrients to a large extent relies on the activity of soil microorganisms and the substrate transformation and synthesis by soil enzymes. The soil microbial properties were significantly correlated with the soil nutrient contents; thus, the soil microbial properties had a major influence on the improvement of soil quality. The stepwise regression analysis revealed that both the soil OC and TN contents were affected by SBR in the $A$. sacrorum communities. In addition, the soil AK content was affected by urease, and soil ON was affected by phosphatase. These findings indicate that SBR, urease activity and phosphatase activity were the major microbial factors affecting the characteristics of the soil nutrients in the $A$. sacrorum communities. In summary, the natural restoration of $A$. sacrorum communities plays a significant role in improving the soil quality in the loess hilly region of northern Shaanxi. Soil nutrient contents and microbial properties mutually affect and facilitate each other to gradually improve soil quality.

\section{Acknowledgments}

We appreciate the support and help of the Ansai Experimental Base for providing adequate facilities and necessary assistance for our experiment. We also thank Shaanxi Forestry Department for providing policy support. Financial support was provided by the Talent Training Program of the West of the Chinese Academy of Sciences (2008DF02) and National Chinese Medicine Resources Survey Project [Finance and Social Work (2017) 66]. We thank anonymous reviewers for their constructive comments that greatly help to improve the manuscript. 


\section{[References]}

[1] Harris J A. Measurements of the soil microbial community for estimating the success of restoration. European Journal of Soil Science, 2003; 54(4): 801-808.

[2] Smith J L. The significance of soil microbial biomass estimation. Soil Biochemistry, 1990; 6: 357-396.

[3] Kaschuk G, Alberton O, Hungria M. Three decades of soil microbial biomass studies in Brazilian ecosystems: lessons learned about soil quality and indications for improving sustainability. Soil Biology and Biochemistry, 2010; 42(1): 1-13.

[4] Wang C F, Shao X H, Xu H L, Chang T T, Wang W N. Effects of compound microbial inoculant treated wastewater irrigation on soil nutrients and enzyme activities. Int J Agric \& Biol Eng, 2016; 9(6): 100-108.

[5] Luo Y Q, Wan S Q, Hui D F, Wallace L L. Acclimatization of soil respiration to warming in a tall, grass prairie. Nature, 2001; 413(6856): 622.

[6] Gil-Sotres F, Trasar-Cepeda C, Leirós M C, Seonae S. Different approaches to evaluating soil quality using biochemical properties. Soil Biology and Biochemistry, 2005; 37(5): 877-887.

[7] Marinari S, Mancinelli R, Campiglia E, Grego S. Chemical and biological indicators of soil quality in organic and conventional farming systems in Central Italy. Ecological Indicators, 2006; 6(4): 701-711.

[8] Han G, Hao X, Zhao M, Ellert B H, Willms W, Wang M J. Effect of grazing intensity on carbon and nitrogen in soil and vegetation in a meadow steppe in Inner Mongolia. Agriculture, Ecosystems \& Environment, 2008; 125(1): 21-32.

[9] An S S, ChengY, Huang Y M, Liu D. Effects of revegetation on soil microbial biomass, enzyme activities, and nutrient cycling on the Loess Plateau in China. Restoration Ecology, 2013; 21(5): 600-607.

[10] Han D X, Wang N, Wang N N, Sun X, Feng F J. Soil microbial functional diversity of different altitude Pinus koraiensis forests. Chinese Journal of Applied Ecology, 2015; 26(12): 3649-3656. (in Chinese)

[11] Pei S, Fu H, Wan C. Changes in soil properties and vegetation following exclosure and grazing in degraded Alxa desert steppe of Inner Mongolia, China. Agriculture, Ecosystems \& Environment, 2008; 124(1): 33-39.

[12] Liu H, Lv J L. Study on soil microbial biomass and soil ecological stoichiometry characteristics under different vegetation type in the Loess Plateau. Acta Agriculturae boreali-occidentalis Sinica, 2016; 25(5): 779-787. (in Chinese)

[13] Bao SD. Soil agrochemical analysis (third edition). Beijing: China agriculture press, 2000; 30-58. (in Chinese)

[14] Vance E, Brookes P, Jenkinson D. An extraction method for measuring soil microbial biomass C. Soil Biology and Biochemistry, 1987; 19(6): 703-707.

[15] Coleman D C, Anderson R V, Cole C V, Elliott E T, Woods L, Campion $\mathrm{M}$ K. Trophic interactions in soil as they affect energy and nutrient dynamics. IV. Flows of metabolic and biomass carbon. Microbial Ecology, 1978; 4: 373-380.

[16] Guan S Y. Soil enzymes and their methods. Beijing: Agricultural press, 2000; 297-198. (in Chinese)

[17] Zhang C, Xue S, Liu G B, Song Z L. A comparison of soil qualities of different revegetation types in the Loess Plateau, China. Plant and Soil, 2011; 347(1-2): 163-178.

[18] Turco R, Kennedy A, Jawson M. Microbial indicators of soil quality. United States: Sssa Special Publication, 1992.

[19] Jordan D, Kremer R J, Bergfield W A, Kim Y K, Cacnio V N. Evaluation of microbial methods as potential indicators of soil quality in historical agricultural fields. Biology and Fertility of Soils, 1995; 19(4): 297-302.

[20] Jobbágy E G, Jackson R B. The distribution of soil nutrients with depth: global patterns and the imprint of plants. Biogeochemistry, 2001; 53(1): 51-77.

[21] Behling H, Pillar V D P. Late Quaternary vegetation, biodiversity and fire dynamics on the southern Brazilian highland and their implication for conservation and management of modern Araucaria forest and grassland ecosystems. Philosophical Transactions of the Royal Society of London B: Biological Sciences, 2007; 362(1478): 243-251.
[22] Monsi M, Saeki T. On the factor light in plant communities and its importance for matter production. Annals of Botany, 2005; 95(3): 549.

[23] Montané F, Romanyà $\mathrm{J}$, Rovira $\mathrm{P}$, Casals $\mathrm{P}$. Aboveground litter quality changes may drive soil organic carbon increase after shrub encroachment into mountain grasslands. Plant and Soil, 2010; 337(1-2): 151-165.

[24] Li Y Y, Dong S K, Wen L, Wang X X, Wu Y. Soil carbon and nitrogen pools and their relationship to plant and soil dynamics of degraded and artificially restored grasslands of the Qinghai-Tibetan Plateau. Geoderma, 2014; 213: 178-184.

[25] Zhao Z P, Yan S, Liu F, Ji P H, Wang X Y, Tong Y A. Effects of chemical fertilizer combined with organic manure on Fuji apple quality, yield and soil fertility in apple orchard on the Loess Plateau of China. Int J Agric \& Biol Eng, 2014; 7(2): 45-55.

[26] Belay A, Claassens A, Wehner F C. Effect of direct nitrogen and potassium and residual phosphorus fertilizers on soil chemical properties, microbial components and maize yield under long-term crop rotation. Biology and Fertility of Soils, 2002; 35(6): 420-427.

[27] Hao W F, Liang Z S, Chen C G. Study on the different succession stage community dynamic and the evolution of soil characteristics of the old-field in Loess Hilly Gully. Chinese Agricultural Science, 2005; 21(8) 226-231. (in Chinese)

[28] Islam K R, Weil R R. Land use effects on soil quality in a tropical forest ecosystem of Bangladesh. Agriculture Ecosystems \& Environment, 2000; 79(1): 9-16.

[29] Dilly O, Munch J C. Microbial biomass content, basal respiration and enzyme activities during the course of decomposition of leaf litter in a black alder (Alnus glutinosa L. Gaertn.) forest. Soil Biology and Biochemistry, 1996; 28(8): 1073-1081.

[30] Badiane N N Y, Chotte J L, Pate E, Masse D, Rouland C. Use of soil enzyme activities to monitor soil quality in natural and improved fallows in semi-arid tropical regions. Applied Soil Ecology, 2001; 18(3): 229-238.

[31] Yan R R, Yan Y C, Xin X P, Yang G H, Wang X, Zhang B H. Changes in microorganisms and enzyme activities in soil under different grazing intensities in meadow steppe, Inner Mongolia. Ecology and Environmental Sciences, 2011; 20(2): 259-265. (in Chinese)

[32] Shaanxi soil census office. Shaanxi soil. Beijing: Science Press, 1992; 410-468. (in Chinese)

[33] Zhou P, Liu G B, Hou X L. Study on vegetation and soil nutrient characters of Artemisia sacrorum communities in hilly-gully region of the loess plateau. Acta Prataculturae Sinica, 2008; 17(2): 9-18. (in Chinese)

[34] Thies J E, Grossman J M. The soil habitat and soil ecology. Biological Approaches to Sustainable Soil Systems, 2006; 59-78.

[35] Blagodatskaya E, Kuzyakov Y. Mechanisms of real and apparent priming effects and their dependence on soil microbial biomass and community structure: critical review. Biology and Fertility of Soils, 2008 45(2): 115-131.

[36] Sardans J, Peñuelas J. Drought decreases soil enzyme activity in a Mediterranean Quercus ilex L. forest. Soil Biology and Biochemistry, 2005; 37(3): 455-461.

[37] Allison S D, Czimczik C I, Treseder K K. Microbial activity and soil respiration under nitrogen addition in Alaskan boreal forest. Global Change Biology, 2008; 14(5): 1156-1168.

[38] Sardans J, Peñuelas J, Estiarte M. Changes in soil enzymes related to C and $\mathrm{N}$ cycle and in soil $\mathrm{C}$ and $\mathrm{N}$ content under prolonged warming and drought in a Mediterranean shrubland. Applied Soil Ecology, 2008; 39(2): 223-235.

[39] Gispert M, Emran M, Pardini G, Doni S, Ceccanti B. The impact of land management and abandonment on soil enzymatic activity, glomalin content and aggregate stability. Geoderma, 2013; 202: 51-61.

[40] Tao B X, Zhang J C, Cui Z H, Kong Y G, Yu Y C. Soil enzyme activity under different forest stands and its correlation with soil physical and chemical characters in the south hilly region of Jiangsu Province. Journal of Ecology and Rural Environment, 2009; 25(2): 44-48.

[41] Zhang W, Qiao W J, Gao D X, Dai Y Y, Deng J, Yang G H et al. Relationship between soil nutrient properties and biological activities along a restoration chronosequence of Pinus tabulaeformis plantation forests in the Ziwuling Mountains, China. Catena, 2018; 161: 85-95. 